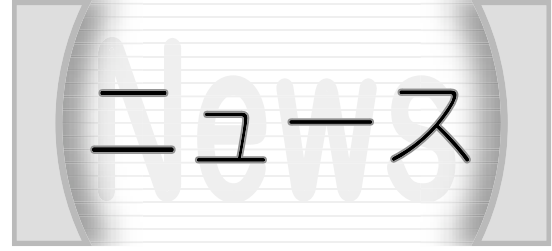

材料・䒺予

C60製トランジスタ

東京大学大学院新領域創成科学研究 科の伊高健治研究員らは, 代表的なナ ノテク材料であるフラーレン (球状炭 素分子)の一種，C60を用いてトランジ ス夕を試作し，基本性能があることを 確認した（図1）.

表面の不純物を取り除いたアルミナ の上に，分子線エピタキシー $(\mathrm{MBE})$ 法で「ペンタセン」と呼ぶ有機分子を一 層敷き，その上にC60分子を50〜80層 積んだ。これまで，ペンタセンを用い ない場合にはn型の特性しか得られな かったが，今回は同じ素子でn型，p型 両方の特性を示した， n型では毎秒 $1 \mathrm{~V}$ 当たり約 $5 \mathrm{~cm}^{2}$ という電子移動度を確 認. 大面積の薄型表示装置に応用可能 な，実用レベルの性能があることを確 認できたと話している.

（日経産業新聞，2007.2.2)

\section{水など液体不要で高い安全性と 携帯性がある固体メタノール燃料}

栗田工業は，燃料電池向けとして発 電時に水などを一切必要としない固体 状メタノール燃料を開発した。

燃料には，メ夕ノールを使って発電 するシステム「ダイレクトメタノール 形燃料電池」(DMFC) に適用する。液 体メタノールに特定の化合物を取り込 ませて固形化する独自の包接化合技術

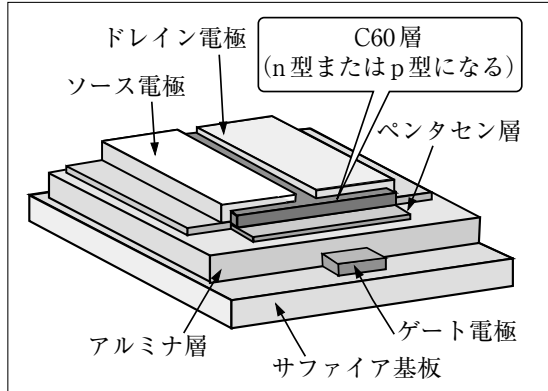

図 1 試作したトランジスタ構造
により実現したという。DMFCに活用 することで，システム本体にも水を供 給することなく発電できるのが特徵.

これまでDMFCは液体メ夕ノールを 用いるのが主流であった。しかし，同 燃料を用いた電源用カートリッジは液

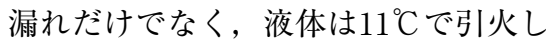
てしまうため, 安全性の観点からも課 題があったという。また，液体のため, 航空機への持ち込み制限などもある. 今回開発した固体用燃料により引火点 は $40^{\circ} \mathrm{C}$ 以上と高くなり，液漏れもない ためこうした課題が解決できる。これ により同燃料を使ったモバイル機器の 電源カートリッジも可能となる．携帯 電話のリチウム電池と比べても, 同じ 大きさであれば2倍長持ちするという。

(日刊工業新聞, 2007.2.7)

\section{格子配列が整えられたGaN基板}

東北大学学際科学国際高等研究セン ターの八百隆文教授らのグループは， 酸化亜鉛 $(\mathrm{ZnO})$ 厚膜を用いて，高品質 で結晶の格子配列が整えられた窒化ガ リウム $(\mathrm{GaN})$ 基板を作製することに成 功した.

従来のサファイア基板上に $\mathrm{GaN}$ 厚膜 を直接成長させる方法では，両基板の 熱膨張係数に差があるため, $\mathrm{GaN}$ 基板 に「歪み」が発生した。

同グループは，まず真空蒸着法を用 いてサファイア基板上に $\mathrm{ZnO}$ 層を形成 し，その上に GaN厚膜を積層．そこへ $900^{\circ} \mathrm{C}$ 程度の条件下で, 活性ガスであ るアンモニアと塩化水素を吹き付け， 化学反応を引き起こした。これにより, $\mathrm{GaN}$ 層が成長する一方で，ZnO層はエ ッチングされ，サファイア基板から $\mathrm{GaN}$ 層が独立.さらに $1040^{\circ} \mathrm{C}$ で別の $\mathrm{GaN}$ 基板厚膜を成長させることで，よ り高品質なGaN厚膜を作製した。

こうして，歪みがほとんどないうえ に高品質な $\mathrm{GaN}$ 基板を得ることができ た。

（日刊工業新聞，2007.2.9）

\section{半導体チップ間の無線高速通信}

慶応大学の黒田教授と石黒講師らは,
重ねた二つの半導体チップ間を高速で 無線通信する技術を開発した (図2).

半導体チップ内に $30 \mu \mathrm{m}$ 角の微細な コイルを加工.コイルが向き合うよう に半導体を重ね，一方にパルス電流を 流す．電磁誘導によってもう一方に電 気信号が生じ，無線通信できる。コイ ルは現在の加工技術でトランジスタの 配線に用いる金属層に作り込む.

約 $15 \mu \mathrm{m}$ の至近距離に置いたコイル 間で1Gbpsの通信ができることを実験 で確認. 1ビットの伝送に必要なエネ ルギーは0.14pJで，従来の約 $1 / 140$.

低消費電力でハイビジョン映画を再 生できるため，高画質の携帯テレビな どに慗がる。

（日経産業新聞，2007.2.20)

\section{RGB3色発光の新結晶}

岩手大学の土岐規仁助教授らは, レ ーザ光を当てると3色に発光する新し いタイプの結晶を開発した (図3).

硫酸カリウム $\left(\mathrm{K}_{2} \mathrm{SO}_{4}\right)$ という無機物 の結晶とアミノベンゼンスルホン酸と いう有機物の結晶を純度の高い水の中 に溶かし，冷却して結晶化した。その 結果, 硫酸カリウムの規則正しい結晶 中に，部分的にアミノベンゼンスルホ ン酸が取り込まれた結晶ができた。

この結晶に波長 $350 \mathrm{~nm}$ のレーザ光を 当てた.アミノベンゼンスルホン酸の 割合を変えることで, 発光色を赤 · 青・緑に変えられることを確認. 当て た光のエネルギーに対する量子効率は 70\%程度だった。これは，「りん光」と いう原理に基づく発光で，有機ELなど に比べ，素材を簡単に合成できるため， 発光装置の大規模化も克服できる.

（日経産業新聞，2006.8.23）

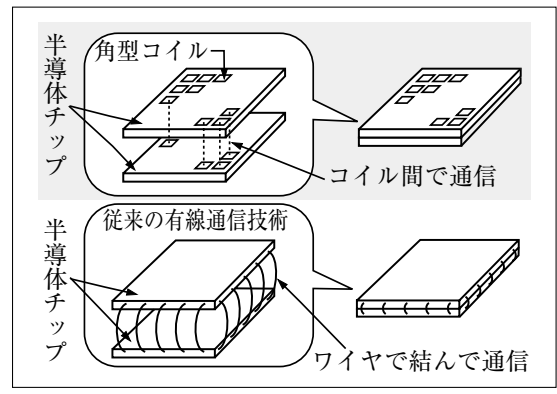

図2 半導体チップ間の無線通信技術 


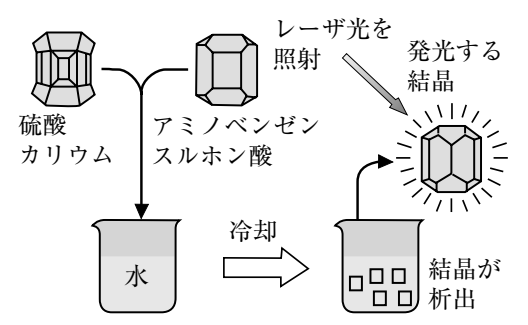

図3 3色に発行する結晶の作り方

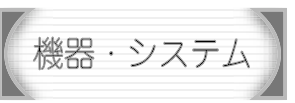

大型有機EL製造装惪

日立造船は，1mの大型基板に対応す る有機ELの製造装置を開発した。有 機ELはガラス基板に発光体を薄膜接 着させてつくるが，新装置は，基板を 従来方法の水平から垂直に変え, 材料 を横から蒸着する．基板のたわみを防 ぎ，従来の 4 倍程度の第 5 世代 $(1,100 \times$ $1,300 \mathrm{~mm})$ パネルも製造できるという. 基板の下から一度に材料を蒸着する 「面蒸着法」は，基板を回転させながら 材料を蒸着する「点蒸着法」に比べて, 材料の利用効率を高められるが, 点蒸 着法と同様に基板を水平にするため， 大型化すると重力によるたわみで蒸着 した材料の膜が均一にならない難点が あった．同社は，たわみを防ぐため基 板を縦にし，横向きに材料を蒸着させ る方法を開発. バルブを制御して材料 の噴出量を調整，既存装置とほぼ同じ 均一さで薄膜をつくることに成功した (図4).

（日経産業新聞，2007.2.9）

\section{波長1.3 $\mu \mathrm{m}$ の単一光子LEDと}

\section{安全性を向上した量子暗号通信}

東芝欧州研究所は，量子暗号通信の 安全性を高める新技術を開発. 光子を 高精度に単一で発生できるLEDを開発 するとともに，デコイ手法とよばれる 盗聴を検知できる技術を実装した。

新開発の単一光子LEDは，既存の光 ファイバ網に適した $1.3 \mu \mathrm{m}$ の量子暗号 用光源. 通常のLED構造の活性層に InAsの量子ドットを埋め込み, 上下に ミラーを配置した共振構造にした。こ れにより複数光子が発生する割合を従

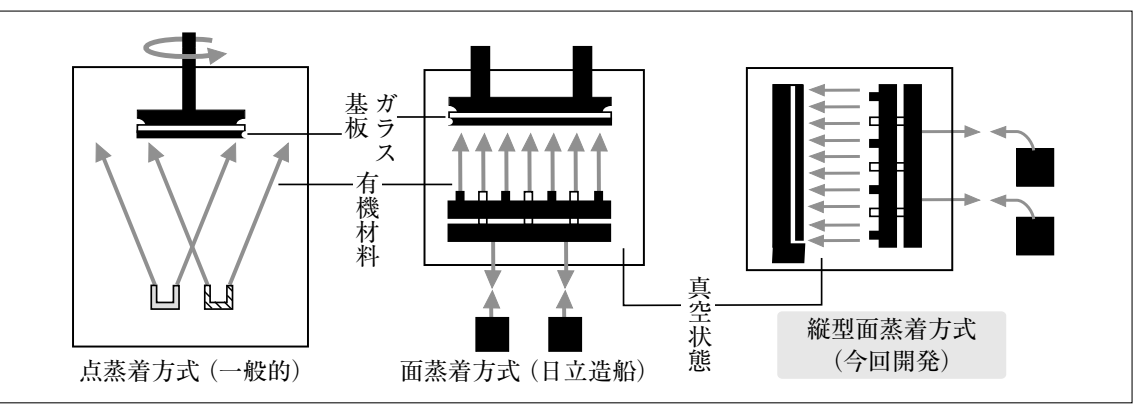

図4 有機ELの製造方法

来の $1 / 5$ に抑えた.

また, 独自開発の「単一方向型」量子 暗号通信にデコイ手法を導入したこと で，より強いパルスで無条件に安全か つ高い配信速度の量子暗号鍵配信を実 現. 実験では， $25 \mathrm{~km}$ の距離を従来の 100倍となる5.5kbpsで配信した。

(日刊工業新聞 - 日経産業新聞 . 電波新聞, 2007.2.21)

\section{高速磁気光による映写技術}

豪州の光技術開発企業であるパノラ マ・ラブズは，映画の海賊版防止に役 立つ高速磁気光技術 (MP) を開発した。

同技術は，ナノスケール構造でピク セルの輝度を $15 \mathrm{~ns}$ という超高速で切替 える。これは，プラズマディスプレイ の1,000倍，液晶ディスプレイの100万 倍速いとしている.

同社は，本技術の特徴として高解像 度, 低初期コスト, 容易な製造技術, 低消費電力, 高信頼性を挙げている. さらには, 画質の大幅改善だけでなく, 海賊版防止や3D画像にも貢献するとい う.

(日経産業新聞, 2007.2.22)

\section{放送規格・ほか}

\section{ホログラムに3 $\mu \mathrm{m}$ の微細文字}

凸版印刷は，見る角度によって模様 や色が変わるホログラムに, $3 \mu \mathrm{m}$ の 超微細文字を書込む技術を開発した. 半導体回路を描く電子ビームを活用, 従来に比べ $1 / 30$ 程度の微細な文字やイ ラスト表現を実現した。 ホログラムは, 3次元映像を記録する写真技術で，素 材の表面に光波の向きと強さによって
決まる「干渉縞」を焼き付けて模様を表 現する.レーザ光を使って描くのが一 般的だが, 微細化は数十 $\mu \mathrm{m}$ が限界で あった。同社は，模様を刻む電子ビー ムを精密に制御するソフトを開発し, ホログラムに $3 \mu \mathrm{m}$ の微細文字を書込 めるようにした．毛髪の幅 (約 $80 \mu \mathrm{m})$ なら20文字以上を書込むことができ る. $5 \mu \mathrm{m}$ 程度の文字の場合，明朝体 など書体を自由に変えることも可能.

(日経産業新聞, 2007.2.1)

\section{中性粒子ビームで直径 $10 \mathrm{~nm}$}

厚さ $2 \mathrm{~nm}$ の円盤構造作成

東北大学の寒川誠二教授らは, 低エ ネルギーで高密度な中性粒子ビームに よる加工技術を開発，直径10nmの円盤 状の微細構造を作ることに成功した。

半導体加工に使うプラズマ装置を改 良し，塩素原子をもとに電荷を持たな い中性粒子ビームを放出する加工装置 を開発した。原子レベルの欠陥につな がるプラズマや紫外線を出さないた め, 精密な加工ができる.

$\mathrm{Si}$ 酸化膜の上に形成した厚さ $2 \mathrm{~nm}$ の 結晶化 $\mathrm{Si}$ の上に，たんぱく質の自己集 積機能を応用して並べた鉄の微粒子を マスクにして加工. 直径 $10 \mathrm{~nm}$, 厚さ 2nmの円盤状の微細構造を作った。こ の構造内を電子が 1 個ずつ移動する量 子効果も計測できた.

(日経産業新聞，2007.2.19）

(その他のニュース)

・超臨場感コミュニケーション産学官

フォーラム

(日刊工業新聞，2007.2.15)

〔執筆担当〕大久保洋幸 委員 $(\mathrm{NHK})$ 吉永 智明 委員 (日立) 